\title{
PENGGUNAAN STRATEGI PEMBELAJARAN KOSA KATA BAHASA ARAB PADA KALANGAN PELAJAR CEMERLANG
}

\section{(THE STRATEGIES USED BY EXCELLENT STUDENTS IN LEARNING NEW ARABIC AFFIXES)}

\author{
Mohd Zaki Ismail ${ }^{1 *}$, Kaseh Abu Bakar ${ }^{2}$, Nik Farhan Nik Mustapha ${ }^{3}$ \\ and Nurazan M Rouyan ${ }^{4}$ \\ ${ }^{1}$ Department of Student Affairs, Institut Pendidikan Guru (IPG) Kampus Pulau Pinang, \\ Persiaran Tunku Kudin, 11700 Gelugor Pulau Pinang, Malaysia \\ ${ }^{2}$ Department of Arabic Studies and Islamic Civilization, Faculty of Islamic Studies, \\ Universiti Kebangsaan Malaysia, 43600, UKM Bangi, Selangor Darul Ehsan, Malaysia \\ ${ }^{3}$ Department of Foreign Languages, Faculty of Modern Languages and Communication, \\ Universiti Putra Malaysia, 43400 Serdang, Selangor, Malaysia \\ ${ }^{4}$ Faculty of Languages and Communication, Universiti Sultan Zainal Abidin, Gong \\ Badak, 21300 Kuala Terengganu, Terengganu, Malaysia \\ *Corresponding author: mozaisma@gmail.com
}

Published date: 20 January 2017

To cite this article: Mohd Zaki Ismail, Kaseh Abu Bakar, Nik Farhan Nik Mustapha, \& Nurazan M Rouyan. (2016). Penggunaan strategi pembelajaran kosa kata bahasa Arab pada kalangan pelajar cemerlang. Asia Pacific Journal of Educators and Education, 31, 47-68. http://dx.doi.org/10.21315/apjee2016.31.4

To link to this article: http://dx.doi.org/10.21315/apjee2016.31.4

\begin{abstract}
Abstrak: Kajian ini merupakan kajian kualitatif yang menggunakan protokol berfikir lantang, pemerhatian dan temu bual sebagai instrumen pungutan data. Ia bertujuan untuk meneroka bentuk strategi yang digunakan oleh pelajar cemerlang ketika mempelajari kosa kata baharu berimbuhan bahasa Arab. Kerangka konseptual kajian ini dibina berasaskan teori strategi pembelajaran bahasa (SPB) dan strategi pembelajaran kosa kata (SPKK). Seramai sembilan pelajar tingkatan enam dari dua buah sekolah dipilih sebagai peserta kajian ini. Mereka diberi tugasan mempelajari 13 kosa kata berimbuhan bahasa Arab. Data protokol berfikir lantang, temu bual dan pemerhatian dianalisis secara manual untuk mencari tema dan diberi kod. Dapatan kajian menunjukkan peserta kajian menggunakan pelbagai strategi pembelajaran kosa kata ketika belajar kosa kata baharu berimbuhan bahasa Arab, namun tahap penggunaan strategi dalam kalangan peserta adalah rendah. Penggunaan strategi yang terhad dan dilaksanakan secara mendatar menuntut guru bahasa Arab untuk mengajarkan kepada para pelajar strategi pembelajaran
\end{abstract}


kosa kata yang lebih efektif. Mereka mesti dibimbing dan dilatih untuk memilih dan menggunakan strategi pembelajaran kosa kata secara berkesan.

Kata Kunci: strategi pembelajaran kosa kata, kosa kata berimbuhan, bahasa Arab, pelajar cemerlang

\begin{abstract}
The purpose of this study is to explore the strategies used by excellent students in learning new Arabic affixes. It is a qualitative study which used think aloud protocols, observation and interviews as data collection instruments. The conceptual framework of this study was based on the theory of language learning strategies (LLS) and vocabulary learning strategies (VLS). A total of nine form six students from two schools were purposely selected as respondents of the study. They have been asked to learn 13 Arabic affixes. The data for 'think aloud' protocol and interviews were analysed, categorised and coded for recurrent themes. The result showed participants used a variety of vocabulary learning strategies when learning new Arabic affixes however, their level of strategy use is low. The learners' limited use of strategies and their superficial application of the strategies imply the need for Arabic teachers to teach students more effective vocabulary learning strategies. They must be taught and trained to select and use vocabulary learning strategies effectively.
\end{abstract}

Keywords: vocabulary learning strategies, Arabic affixes, Arabic language, excellent student

\title{
PENGENALAN
}

Kajian tentang strategi pembelajaran kosa kata adalah berasal dari rangkaian penyelidikan strategi pembelajaran yang bermula pada awal tahun 70-an (Rubin, 1975; Stern, 1975; Naiman, Fröhlich, Stern, \& Todesco, 1978). Rententan daripada kajian tersebut lahirlah pelbagai istilah tentang strategi pembelajaran bahasa. Rubin (1975) mentakrifkan strategi pembelajaran bahasa sebagai teknik atau alat yang digunakan oleh pelajar untuk memperoleh sesuatu pengetahuan. Wenden dan Rubin (1987) pula mentakrifkannya sebagai set operasi yang digunakan oleh pelajar untuk memudahkan pemerolehan, penyimpanan, mendapatkan semula dan menggunakan maklumat. Sementara itu Oxford (1990) mentakrifkan strategi pembelajaran bahasa sebagai tindakan tertentu yang diambil oleh pelajar supaya pembelajaran menjadikan lebih mudah, lebih cepat, lebih menyeronokkan, lebih bersifat kendiri, lebih berkesan dan berpindah kepada suasana baharu.

Dapatan kajian pemerolehan bahasa menunjukkan gaya dan strategi pembelajaran merupakan salah satu daripada faktor perbezaan pelajar dalam pembelajaran bahasa kedua. Dalam hal ini pelajar bahasa yang baik pencapaiannya menangani cara pembelajaran bahasa kedua dengan cara yang berbeza berbanding mereka 
yang kurang baik pencapaian (Cook, 2013). Lantaran itulah pengetahuan tentang strategi pelajar dapat membantu guru bahasa untuk melaksanakan aktiviti pengajaran dan pembelajaran dengan lebih efektif. Menurut Rubin (1975) sekiranya kita mengetahui dengan lebih lanjut mengenai apa yang dilakukan oleh pelajar yang berjaya, kita mungkin boleh mengajar strategi ini kepada pelajar yang kurang berjaya untuk meningkatkan kejayaan mereka.

Dalam konteks pembelajaran bahasa Arab di Malaysia, kajian tentang strategi pembelajaran kosa kata sangat kurang dilakukan. Kebanyakan kajian yang dilakukan pula lebih berfokus kepada kosa kata secara umum dan tidak menjurus kepada jenis tertentu. Lantaran itulah kajian ini dilaksanakan untuk meneroka strategi pembelajaran kosa kata berimbuhan bahasa Arab. Hal ini demikian kerana ciri bahasa Arab yang paling jelas ialah sebahagian besar perkataannya dibina dari kata dasar atau kata akar. Melalui penambahan awalan, sisipan dan akhiran dengan menggunakan pola tertentu, maka terbentuklah satu perkataan baharu (Al-Shuwairekh, 2001).

Pengimbuhan kata merupakan salah satu sumber penting untuk memperkaya makna kata kerja bahasa Arab dan cara yang fleksibel untuk menyampaikan makna sesuatu tindakan (Al-Kufi, 2009). Terdapat dua bentuk pengimbuhan terhadap kosa kata bahasa Arab, iaitu pengulangan bunyi yang sama seperti pada pola kata kerja berimbuhan (فَعَسْل - افْحَـنَّ) dan penambahan imbuhan seperti pada pola kata kerja berimbuhan (فاعل - فاعسل) (Al-Ghalayini, 1993; AlShamsani, 1997; Qabawah, 1988; Al-Thamaniniyy, 1999; Al-Afghani, 2003). Kosa kata berimbuhan yang dimaksudkan dalam kajian ini ialah kosa kata yang menerima kedua-dua bentuk pengimbuhan ini iaitu kata kerja lampau.

\section{TINJAUAN LITERATUR}

Strategi pembelajaran adalah alat yang penting untuk membantu pelajar menguasai sesuatu pelajaran. Ia merupakan langkah atau tindakan khusus yang diambil oleh pelajar untuk memudahkan pemerolehan, penyimpanan, pemerolehan semula dan penggunaan maklumat (Rigney, 1978). Pelajar menggunakan strategi dalam pembelajaran mereka untuk meningkatkan pembelajaran diri mereka sendiri (Oxford, 1990). Menurut Zamri dan Mohamed Amin (2005) penggunaan strategi dalam pembelajaran merupakan satu cara untuk membantu seseorang berjaya menguasai sesuatu pelajaran dan pelajar yang menggunakan pelbagai strategi pembelajaran bahasa dapat membantu mereka berjaya dalam pelajaran bahasa. Strategi pembelajaran kosa kata merujuk kepada teknik atau tindakan yang digunakan oleh pelajar bahasa untuk memudahkan mereka memperoleh, memahami, menyimpan, mengingatkan semula dan mengembangkan pengetahuan kosa kata yang baharu dipelajari supaya 
pembelajaran menjadi lebih cepat, berkesan, bersifat kendiri dan menyeronokkan (Intaraprasert, 2004; Cameron, 2001; Schmitt, 1997).

Kajian strategi pembelajaran kosa kata telah dilaksanakan dalam pelbagai tema. Sebahagiannya mengkaji penggunaan strategi dalam mempelajari kosa kata (seperti Lawson \& Hogben (1996); Mohd. Sahandri, Kafipiur \& Saifuddin(2009); Asgari \& Ghazali (2011)), sebahagian yang lain mengkaji perkaitan penggunaan strategi dengan pemboleh ubah yang lain (contoh; persekitaran: Dakun (2006); gender: Catalan (2003)), dan sebahagian lain pula mengkaji penggunaan strategi khusus dalam pembelajaran kosa kata (contoh; strategi pemetaan semantik: Norhayuza (2006); strategi kata kunci: Khoury (2008); Jawlah Lughawiyyah : Wan Abdul Hayyi, Mohd Shahrizal, Mohd Firdaus, \& Zulazhan (2014)).

Selain daripada kepelbagaian tema, kajian penggunaan strategi pembelajaran kosa kata juga dilakukan terhadap pelbagai bahasa. Sanaoui (1995) meneroka penggunaan strategi pembelajaran kosa kata bahasa Inggeris dan bahasa Perancis. Lawson dan Hogben (1996) mengkaji penggunaan kaedah kata kunci dalam pembelajaran kosa kata bahasa Itali. Catalan (2003) pula mengkaji perbezaan gender dalam penggunaan strategi pembelajaran kosa kata penutur bahasa Sepanyol yang mempelajari Basque dan Bahasa Inggeris sebagai bahasa kedua. $\mathrm{Fu}$ (2005) mengkaji penggunaan strategi pembelajaran kosa kata untuk mempelajari bahasa Cina. Sagarra dan Alba (2006) mengkaji keberkesanan tiga kaedah pembelajaran perbendaharaan kata bahasa Sepanyol sebagai bahasa kedua.

Penggunaan strategi pembelajaran kosa bahasa Arab turut dilakukan oleh beberapa kajian. Al-Shuwairekh (2001) mengkaji penggunaan strategi pembelajaran kosa dalam kalangan pelajar cemerlang dan lemah. Khoury (2008) mengkaji kefahaman pelajar terhadap proses morfologi dalam membuat kesimpulan makna perkataan yang tidak diketahui. Norhayuza (2006) meninjau kesan penggunaan Strategi Pemetaan Semantik (SPS). Mufidah (2008) pula meneliti keberkesanan penggunaan Kaedah Kata kunci dalam pemerolehan perbendaharaan kata bahasa Arab di kalangan pelajar sekolah menengah. Kajian Wan Abdul Hayyi et al. (2014) bertujuan untuk menilai keberkesanan penggunaan aktiviti Jawlah Lughawiyyah untuk menguasai kosa kata bahasa Arab. Nik Mohd Rahimi, Zahriah dan Wan Normeza (2014) mengkaji penggunaan aturan kluster Semantik dan aturan kluster bebas dalam pembelajaran kosa kata bahasa Arab.

Beberapa kajian terkini strategi pembelajaran kosa kata bahasa Arab di Malaysia lebih bersifat kajian penerokaan. Alhashemi dan Mahmoud (2012) mengkaji penggunaan strategi pembelajaran kosa kata dalam kalangan pelajar tahun 
pertama universiti di Malaysia. Kajian Harun dan Zawawi (2014) meneroka hubungan penggunaan strategi pembelajaran kosa kata dengan saiz kosa kata pelajar. Nik Hanan dan Rabiatul Aribah (2014) juga mengkaji penggunaan strategi pembelajaran kosa kata dalam kalangan pelajar bahasa Arab Universiti Islam Antarabangsa Malaysia. Kajian Harun (2014) terhadap 742 pelajar pra universiti juga bertujuan untuk meneroka penggunaaan strategi semasa mempelajari kosa kata bahasa Arab. Kajian Rabiatul Aribah, Nik Hanan, Tg Ainul Farha dan Nadhilah (2014) membandingkan penggunaan strategi pembelajaran kosa kata antara pelajar pengkhususan bahasa Arab dengan bukan pengkhususan bahasa Arab di Universiti Islam Antarabangsa Malaysia (UIAM). Dapatan kajian menunjukkan tiada perbezaan yang signifikan antara dua kumpulan tersebut.

Sorotan literatur yang telah dilakukan menunjukkan penggunaan strategi pembelajaran kosa kata boleh diaplikasikan untuk mempelajari semua jenis bahasa. Hal ini demikian kerana strategi pembelajaran kosa kata mempunyai beberapa persamaan dengan teori bagaimana maklumat disimpan di dalam sistem ingatan manusia. Model pemprosesan maklumat yang dikemukakan oleh pakar psikologi kognitif seperti Atkinson dan Shiffrin (1968), Anderson (1983) dan Gagne (1993), menjelaskan tiga tahap ingatan yang bertindak balas terhadap sesuatu maklumat, iaitu ingatan deria, ingatan jangka pendek atau bekerja dan ingatan jangka panjang. Merujuk kepada cara sistem ingatan manusia beroperasi seperti yang didedahkan oleh teori kognitif pemprosesan maklumat, penggunaan strategi pembelajaran kosa kata yang sesuai dapat membantu pelajar untuk menyimpan maklumat bahasa ke dalam sistem ingatan dengan lebih berkesan. Peranan strategi pembelajaran dalam proses pembelajaran kognitif adalah untuk menjadikan maklumat yang diterima bersifat eksplisit dan pembelajaran berlaku dengan cekap supaya penyimpanan dalam ingatan jangka panjang menjadi lengkap (Takač, 2008).

\section{PERNYATAAN MASALAH}

Kajian bidang pengajaran dan pembelajaran kosa kata di Malaysia masih kurang mendapat perhatian di dalam kalangan pengkaji. Menurut Norhayuza (2006), kajian bidang kosa kata bahasa Arab masih belum meluas dan jauh ketinggalan jika dibandingkan dengan kajian bidang yang sama di dalam bahasa lain seperti bahasa Inggeris. Kekurangan kajian dalam aspek strategi penguasaan kosa kata menyebabkan bidang pengajaran bahasa Arab kekurangan maklumat yang boleh digunakan untuk mengatasi permasalahan yang timbul dalam pembelajaran bahasa Arab secara umum dan dalam penguasaan kosa kata secara khusus. 
Berdasarkan kepada sorotan literatur yang dilakukan, pengkaji mendapati kajian tentang strategi pembelajaran kosa kata adalah bersifat umum dan tidak menjurus kepada jenis kosa kata tertentu. Lantaran itu bidang pembelajaran kosa kata tertentu seperti kosa kata berimbuhan tidak mempunyai maklumat empirikal tentang strategi yang digunakan oleh pelajar ketika mempelajari kosa kata tersebut. Pengetahuan tentang strategi adalah penting kerana ia meningkatkan kesedaran terhadap tindakan yang dilakukan oleh seseorang (Nunan, 1999). Menurut Abhakorn (2008), semakin banyak kita belajar tentang strategi pelajar semakin meningkat pengetahuan kita tentang kompleksnya pembelajaran bahasa. Guru yang mempelbagaikan strategi pengajaran dapat membantu pelajarnya menguasai pelbagai ilmu bahasa dengan cepat dan berkesan (Oxford \& Crookall, 1989).

\section{TUJUAN KAJIAN}

Kajian ini bertujuan untuk mengenal pasti strategi pembelajaran kosa kata yang digunakan oleh pelajar cemerlang ketika mempelajari kosa kata berimbuhan bahasa Arab. Aspek yang dikaji adalah berkaitan dengan strategi pembelajaran kosa kata yang digunakan untuk mengenal pasti makna dan mengukuhkan penguasaan makna tersebut. Penggunaan pelbagai strategi pembelajaran kosa kata dapat membantu pelajar mempelajari kosa kata berimbuhan dengan lebih efektif.

\section{METODOLOGI KAJIAN}

Kajian yang dilaksanakan ini menggunakan pendekatan kualitatif dan berbentuk penerokaan strategi pembelajaran kosa kata berimbuhan bahasa Arab yang digunakan oleh pelajar cemerlang. Namun, data yang terhasil selepas analisis data dilakukan adalah data kuantitatif. Hal ini demikian kerana tujuan kajian adalah untuk meneroka jenis dan bilangan strategi serta kekerapan penggunaan bagi setiap strategi. Menurut Creswell (2012) kajian yang bertujuan untuk meneroka suatu fenomena yang tidak mempunyai maklumat yang banyak daripada sorotan literatur sangat sesuai menggunakan pendekatan kualitatif. Reka bentuk kualitatif juga merupakan pendekatan naturalistik yang bertujuan untuk memahami fenomena dalam persekitaran sebenar dan pengkaji tidak memanipulasikan fenomena untuk tujuan kajian (Patton, 1990).

Data kajian ini diperoleh melalui kajian lapangan dengan menggunakan kaedah protokol perlantangan fikiran, pemerhatian dan temu bual. Perlantangan fikiran adalah satu pendekatan yang memberi tumpuan kepada pengalaman pembelajaran yang membolehkan peserta kajian memberi tumpuan kepada apa 
yang sedang mereka lakukan (Cotton \& Gretsy, 2006). Melalui prosedur ini penyelidik dapat menemui apakah jenis atau proses pemikiran atau strategi yang digunakan oleh pelajar semasa melaksanakan tugasan pembelajaran (Richards \& Schmidt, 2002).

Data kajian ini diambil daripada sembilan orang pelajar tingkatan enam yang sedang belajar di dua buah sekolah agama di negeri Pulau Pinang dan Kelantan. Mereka adalah pelajar yang memperoleh keputusan sekurang-kurangnya pangkat A untuk bahasa Arab di peringkat Sijil Pelajaran Malaysia (SPM). Para pelajar ini diberi tugasan mempelajari 13 kosa kata berimbuhan bahasa Arab dengan menggunakan kaedah protokol perlantangan fikiran. Bilangan perkataan tersebut adalah mencukupi untuk kajian penerokaan yang menggunakan pendekatan protokol perlantangan fikiran. Kajian Lawson dan Hogben (1996) yang juga merupakan kajian penerokaan penggunaan strategi pembelajaran kosa kata menggunakan 12 kosa kata. Pemilihan kosa kata tersebut adalah mengikut kriteria berikut:

1. Kosa kata berimbuhan yang dipilih adalah kosa kata yang tidak diketahui maknanya oleh responden kajian.

2. Kosa kata berimbuhan tersebut merupakan kata kerja lampau tiga akar berimbuhan. Hal ini kerana kata kerja tiga akar merupakan kata kerja majoriti dalam bahasa Arab.

3. Kata kerja berimbuhan tersebut mewakili sembilan jenis pola kata kerja tiga akar.

Data kualitatif daripada perlantangan fikiran, pemerhatian dan temu bual telah ditranskripsikan kepada bentuk tulisan secara perkataan demi perkataan (verbatim). Selepas mengenal pasti tema daripada data yang telah siap ditranskripsikan, proses pengekodan telah dilaksanakan mengikut taksonomi Schmitt (1997). Rasional pemilihan pengklasifikasian Schmitt (1997) sebagai asas untuk melakukan pengekodan data adalah berdasarkan kepada pengklasifikasiannya yang lebih terperinci. Proses pengekodan data kajian ini dipandu oleh lapan langkah yang dicadangkan oleh Tesch (1990). Salah satu daripadanya ialah menggunakan singkatan bagi setiap kategori. Kajian ini menggunakan singkatan seperti Jadual 1. 
Mohd Zaki Ismail et al.

Jadual 1. Singkatan nama strategi

\begin{tabular}{lc}
\hline Strategi & Singkatan \\
\hline Strategi Mencari Makna Kosa Kata & CM \\
Strategi Penentuan & SP \\
Strategi Sosial & SS \\
Strategi Unsur Islam & S1 \\
Strategi Mengingat Makna Kosa Kata & IM \\
Strategi Kognitif & SK \\
Strategi Memori & SM \\
Strategi Meta Kognitif & SMK \\
\hline
\end{tabular}

Untuk menganalisis kekerapan penggunaan strategi dalam kalangan responden kajian, protokol seperti Jadual 2 telah digunakan.

Jadual 2. Contoh protokol analisis kekerapan penggunaan strategi pembelajaran setiap kosa kata berimbuhan bagi setiap responden

\begin{tabular}{|c|c|c|c|c|c|c|}
\hline \multirow[t]{2}{*}{ Bil } & \multicolumn{3}{|c|}{ Mencari makna kosa kata $(\mathrm{CM})$} & \multicolumn{3}{|c|}{ Mengingati makna kosa kata (IM) } \\
\hline & Jenis strategi & Kod & $f$ & Jenis strategi & Kod & $f$ \\
\hline \multirow[t]{3}{*}{ K1 } & Bacaan basmalah & SP & 1 & 1. Mengulangi sebutan & SK & 2 \\
\hline & $\begin{array}{l}\text { 2. Menyebut perkataan } \\
\text { baru dengan kuat }\end{array}$ & SP & 2 & Menggunakan kad imbas & SK & 2 \\
\hline & 3. Membaca ayat contoh & SP & 2 & Menyebut dengan kuat & SM & 1 \\
\hline
\end{tabular}

Analisis pengaplikasian strategi pembelajaran kosa kata berimbuhan daripada data perlantangan fikiran, pemerhatian dan temu bual bagi setiap responden dilakukan dengan menggunakan protokol seperti Jadual 3.

Jadual 3. Contoh protokol analisis pengaplikasian strategi pembelajaran kosa kata berimbuhan

\begin{tabular}{|c|c|c|c|c|c|c|}
\hline \multirow{2}{*}{ Bil } & \multicolumn{3}{|c|}{$\begin{array}{l}\text { Strategi mencari makna kosa kata } \\
\qquad(\mathrm{CM})\end{array}$} & \multicolumn{3}{|c|}{$\begin{array}{l}\text { Strategi mengingat makna kosa kata } \\
\text { (IM) }\end{array}$} \\
\hline & $\begin{array}{l}\text { Cara pengaplikasian } \\
\text { strategi }\end{array}$ & Kod & $f$ & $\begin{array}{l}\text { Cara pengaplikasian } \\
\text { strategi }\end{array}$ & Kod & $f$ \\
\hline \multirow[t]{4}{*}{ Peserta 1} & Menyebut dengan kuat & SP & 2 & Mengulangi sebutan & SK & 2 \\
\hline & Bertanya guru & SS & 1 & $\begin{array}{l}\text { Hubungkan dengan } \\
\text { sinonim }\end{array}$ & SM & 1 \\
\hline & & & & $\begin{array}{l}\text { Uji diri dengan ujian } \\
\text { perkataan }\end{array}$ & SMK & 1 \\
\hline & Jumlah & 2 & 3 & Jumlah & 3 & 4 \\
\hline
\end{tabular}




\section{Kerangka Teori}

Model kajian yang diadaptasikan untuk kajian ini adalah berdasarkan kepada dua model iaitu Model Pemerolehan Bahasa Kedua Ellis (1985) dan Model Klasifikasi Strategi Pembelajaran Kosa Kata Schmitt (1997). Kesesuaian model ini dengan bidang kajian adalah kerana ia bersifat komprehensif dan merangkumi domain utama yang mempengaruhi proses pembelajaran. Ellis (1985) mengemukakan empat faktor pemerolehan bahasa, iaitu faktor situasi, input linguistik, perbezaan individu dan proses pelajar. Ringkasan model ini dapat dilihat melalui Rajah 1.

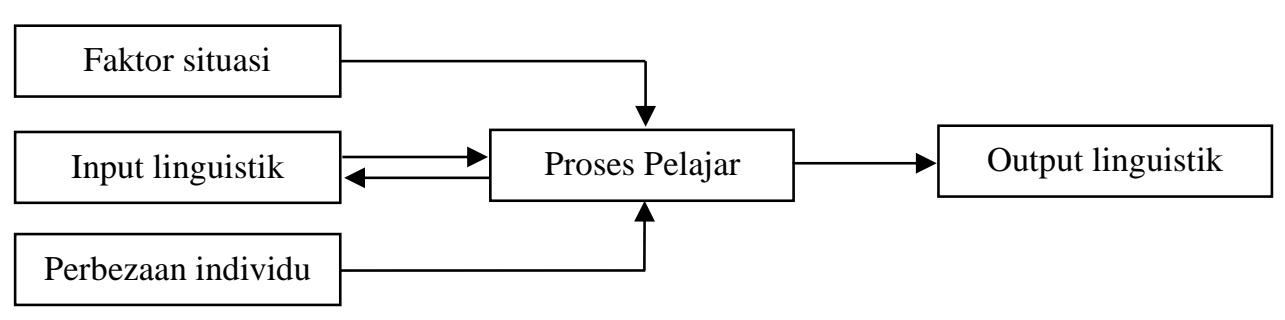

Rajah 1. Model pemerolehan bahasa kedua Ellis (1985)

Sementara itu model klasifikasi Schmitt (1997) pula terbahagi kepada dua kumpulan utama, iaitu: strategi penemuan yang melibatkan pembelajaran maksud perkataan baharu dan strategi penyatuan yang melibatkan pemantapan penguasaan makna kosa kata baharu dan penyimpanannya ke dalam sistem ingatan jangka panjang. Klasifikasi ini memperlihatkan kedua-dua aspek, iaitu pemahaman dan produksi. Ringkasan klasifikasi Schmitt (1997) dapat dilihat melalui Rajah 2.

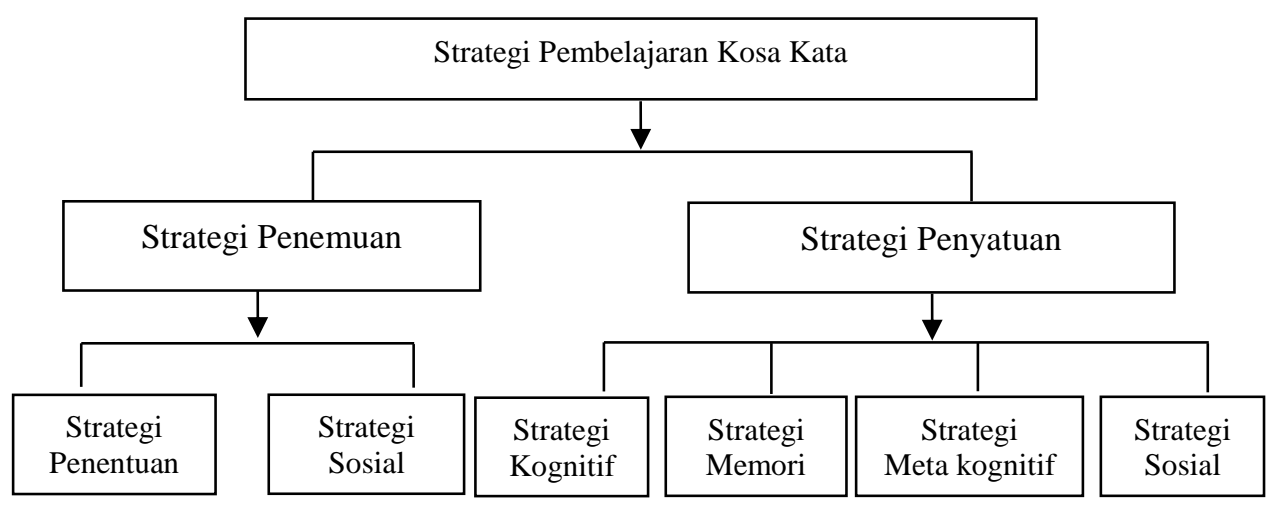

Rajah 2. Model klasifikasi strategi pembelajaran kosa kata Schmitt (1997) 


\section{DAPATAN KAJIAN}

Secara umumnya peserta kajian menggunakan pelbagai strategi ketika mempelajari kosa kata berimbuhan bahasa Arab. Kekerapan penggunaan strategi juga pelbagai dan berbeza-beza antara satu sama lain.

\section{Analisis Strategi Untuk Mempelajari Kosa Kata Berimbuhan Bahasa Arab}

Analisis strategi yang digunakan untuk mempelajari kosa kata dibahagikan kepada beberapa bahagian seperti berikut:

\section{Analisis kategori strategi dan kekerapan penggunaan}

Analisis kategori strategi yang diaplikasikan dalam kajian ini adalah mengikut pengklasifikasian Schmitt (1997). Dapatan analisis data protokol perlantangan fikiran dan temu bual menunjukkan peserta kajian menggunakan kedua-dua kategori strategi pembelajaran kosa kata iaitu strategi penemuan dan pengukuhan ketika mempelajari kosa kata baharu berimbuhan. Kekerapan penggunaan strategi berdasarkan data protokol perlantangan fikiran dipaparkan melalui Jadual 4.

Jadual 4. Jenis strategi dan kekerapan penggunaan ketika mempelajari kosa kata berimbuhan bahasa Arab

\begin{tabular}{lcccccccccc}
\hline \multirow{2}{*}{ Strategi } & \multicolumn{10}{c}{ Peserta } \\
\cline { 2 - 10 } & 1 & 2 & 3 & 4 & 5 & 6 & 7 & 8 & 9 & Jumlah \\
\hline Penemuan & 80 & 81 & 87 & 101 & 72 & 75 & 118 & 101 & 73 & 788 \\
Pengukuhan & 73 & 89 & 88 & 77 & 84 & 88 & 85 & 73 & 100 & 757 \\
\hline Jumlah & 153 & 170 & 175 & 178 & 156 & 163 & 203 & 174 & 173 & 1545 \\
\hline
\end{tabular}

Kekerapan minimum penggunaan strategi penemuan untuk mencari makna kosa kata ialah tujuh dua kali dan kekerapan maksimumnya ialah 118 kali. Kekerapan minimum strategi pengukuhan makna pula ialah 73 kali dan kekerapan maksimumnya ialah 100 kali. Jurang perbezaan kekerapan penggunaan di antara strategi penemuan dan pengukuhan ialah 31 kali.

\section{Cara pengaplikasian strategi mempelajari kosa kata baharu berimbuhan}

Analisis cara pengaplikasian strategi menunjukkan enam jenis strategi utama telah digunakan oleh peserta kajian. Strategi tersebut ialah strategi penentuan, kognitif, memori, meta kognitif, sosial dan unsur Islam. Dapatan analisis juga menunjukkan peserta kajian mengaplikasikan sekurang-kurang lima jenis strategi 
semasa mempelajari kosa kata. Jadual 5 menjelaskan secara terperinci jenis strategi dan bilangan peserta yang menggunakan strategi tersebut.

Jadual 5. Strategi yang diaplikasikan untuk mempelajari kosa kata berimbuhan dan bilangan kekerapan penggunaan

\begin{tabular}{cccccccc}
\hline & \multicolumn{7}{c}{ Strategi } \\
\cline { 2 - 6 } Peserta & Penentuan & Kognitif & Memori & $\begin{array}{c}\text { Meta } \\
\text { Kognitif }\end{array}$ & Sosial & Islam & Jumlah \\
\hline 1 & 79 & 45 & 28 & - & - & 1 & 153 \\
2 & 80 & 63 & 22 & 4 & & 1 & 170 \\
3 & 86 & 42 & 46 & - & - & 1 & 175 \\
4 & 100 & 57 & 20 & - & - & 1 & 178 \\
5 & 71 & 63 & 21 & - & - & 1 & 156 \\
6 & 74 & 57 & 31 & - & - & 1 & 163 \\
7 & 117 & 47 & 32 & - & - & 7 & 203 \\
8 & 98 & 53 & 20 & - & 2 & 1 & 174 \\
9 & 70 & 59 & 38 & - & 2 & 4 & 173 \\
\hline Jumlah & 775 & 486 & 258 & 4 & 4 & 18 & 1545 \\
\hline
\end{tabular}

\section{Analisis kekerapan pengaplikasian setiap strategi}

Dapatan analisis kekerapan pengaplikasian setiap strategi utama daripada data protokol perlantangan fikiran menunjukkan strategi penentuan adalah strategi yang paling tinggi kekerapan penggunaan dengan bilangan 775 kali penggunaan. Ia diikuti oleh strategi kognitif dengan bilangan 486 kali, strategi memori dengan 258, strategi unsur Islam dengan 17 kali, strategi sosial dengan 11 kali dan strategi meta kognitif dengan 4 kali penggunaan. Dapatan analisis juga menunjukkan jurang perbezaan di antara strategi yang paling kerap digunakan dengan yang paling kurang digunakan sangat besar.

Dapatan analisis menunjukkan kekerapan minimum penggunaan strategi penentuan ialah 70 kali dan kekerapan maksimumnya ialah 117 kali. Kekerapan minimum penggunaan strategi kognitif pula ialah sebanyak 42 kali dan kekerapan maksimumnya ialah 63 kali. Kekerapan minimum penggunaan strategi memori ialah 20 kali dan kekerapan maksimumnya ialah 46 kali. Kekerapan minimum penggunaan strategi unsur Islam ialah sekali penggunaan dan kekerapan maksimumnya ialah empat kali. Kekerapan minimum penggunaan strategi sosial ialah satu kali dan kekerapan maksimum dua kali. Strategi meta kognitif tidak mempunyai kekerapan minimum dan maksimum. Strategi ini diaplikasikan oleh 
seorang peserta sahaja. Penjelasan secara terperinci kekerapan minimum dan maksimum setiap strategi dipaparkan melalui Jadual 5.

\section{Analisis Cara Mengaplikasikan Strategi Pembelajaran Untuk Mengenal Pasti Makna}

Analisis cara pelajar mengaplikasikan strategi untuk mencari dan mengenal pasti makna kosa kata baharu berimbuhan adalah seperti berikut.

\section{Analisis strategi utama}

Dapatan analisis data protokol perlantangan fikiran dan temu bual menunjukkan peserta kajian mengaplikasikan tiga strategi utama iaitu strategi penentuan, strategi unsur Islam dan strategi sosial untuk mengenal pasti makna kosa kata. Jadual 6 menjelaskan secara terperinci jenis strategi utama dan bilangan penggunaan oleh setiap peserta kajian.

Jadual 6. Strategi untuk mengenal pasti makna kosa kata dan kekerapan penggunaan

\begin{tabular}{|c|c|c|c|c|}
\hline $\begin{array}{l}\text { Strategi } \\
\text { Utama }\end{array}$ & Sub-strategi & Jumlah & $\begin{array}{l}\text { Bilangan } \\
\text { Pengguna }\end{array}$ & Kekerapan \\
\hline \multirow[t]{18}{*}{ Penentuan } & Guna kad imbas & 18 & 9 & 105 \\
\hline & Sebut dengan kuat & & 9 & \\
\hline & Baca ayat contoh & & 9 & \\
\hline & Analisis pola & & 9 & \\
\hline & Menghubungkan kosa kata dengan sinonim & & 4 & \\
\hline & guna kamus & & 7 & \\
\hline & Menghubungkan kosa kata dengan antonim & & 9 & \\
\hline & teks dari konteks & & 8 & \\
\hline & Terjemah ayat & & 8 & \\
\hline & Guna gambar & & 8 & \\
\hline & Analisis imbuhan & & 3 & \\
\hline & Analisis kata dasar & & 9 & \\
\hline & Analisis pembentukan kata & & 4 & \\
\hline & Mencatat & & 8 & \\
\hline & Pengetahuan lepas & & 5 & \\
\hline & Analisis pembentukan ayat & & 1 & \\
\hline & Hubungkan dengan bahasa ibunda & & 1 & \\
\hline & Guna peribahasa & & 2 & \\
\hline \multirow[t]{2}{*}{ Sosial } & Bertanya guru & 2 & 9 & 11 \\
\hline & Bertanya rakan & & 2 & \\
\hline Unsur Islam & Bacaan basmalah & 1 & 9 & 9 \\
\hline Jumlah & & 21 & & 125 \\
\hline
\end{tabular}




\section{Analisis sub strategi}

Dapatan analisis data menunjukkan 18 jenis sub strategi penentuan telah diaplikasikan oleh peserta kajian. Daripada jumlah tersebut, lapan jenis sub strategi telah diaplikasikan oleh semua peserta dan dua jenis sub strategi diaplikasikan oleh seorang peserta untuk setiap satu. Paparan secara terperinci dapat dilihat dalam Jadual 6 .

Jadual 6 menunjukkan kekerapan penggunaan strategi penentuan mencapai bilangan 105 kali penggunaan. Enam strategi berikut iaitu strategi menggunakan kad imbas, strategi menyebut dengan kuat, strategi membaca ayat, strategi analisis pola, strategi menghubungkan kosa kata dengan sinonim dan strategi menggunakan kamus telah diaplikasikan oleh semua peserta kajian. Sementara itu dua sub strategi iaitu strategi analisis pembentukan ayat, strategi hubungkan dengan bahasa ibunda dan strategi menggunakan peribahasa diaplikasikan setiap satunya oleh seorang peserta sahaja. Strategi menghubungkan kosa kata dengan antonim, strategi menterjemahkan ayat dan strategi meneka dari konteks telah diaplikasikan oleh lapan peserta. Lima strategi lagi telah diaplikasikan oleh dua hingga tujuh orang peserta untuk setiap satu daripadanya.

Dapatan analisis juga menunjukkan peserta kajian mengaplikasikan dua jenis sub strategi sosial iaitu bertanya guru dan bertanya rakan ketika mencari makna kosa kata. Strategi bertanya guru diaplikasikan oleh semua peserta manakala strategi bertanya rakan diaplikasikan oleh dua peserta sahaja. Jadual 6 menunjukkan peserta kajian lebih cenderung untuk bertanya guru berbanding bertanya rakan untuk mengenal pasti makna kosa kata baharu.

\section{Cara Mengaplikasikan Strategi Pembelajaran Untuk Pengukuhan Makna}

Berikut adalah paparan dapatan analisis strategi yang diaplikasikan oleh peserta kajian untuk tujuan tersebut.

\section{Strategi utama pengukuhan makna}

Dapatan analisis data perlantangan fikiran dan temu bual setelah proses koding tema dilakukan, menunjukkan lima strategi utama untuk pengukuhan makna kosa kata. Strategi tersebut ialah strategi kognitif, strategi memori, strategi sosial, strategi meta kognitif dan strategi unsur Islam. Dapatan analisis juga menunjukkan strategi kognitif dan strategi memori menjadi pilihan peserta untuk mengukuhkan makna yang telah dikuasai berbanding tiga lagi strategi lain. Jumlah kekerapan penggunaan strategi utama untuk pengukuhan makna ialah 
sebanyak 23 kali. Maklumat lebih terperinci bentuk strategi yang digunakan adalah seperti Jadual 7.

Jadual 7. Strategi untuk pengukuhan makna kosa kata dan kekerapan penggunaan

\begin{tabular}{|c|c|c|c|}
\hline Strategi utama & Sub strategi & Bilangan sub strategi & Bilangan pengguna \\
\hline \multirow[t]{12}{*}{ Kognitif } & Guna kad imbas & 12 & 9 \\
\hline & Ulang sebutan & & 9 \\
\hline & Baca ayat contoh & & 9 \\
\hline & Terjemahkan ayat & & 9 \\
\hline & Mencatat & & 8 \\
\hline & Analisis pembentukan kata & & 7 \\
\hline & Analisis pola & & 6 \\
\hline & Guna gambar & & 4 \\
\hline & Analisis kata dasar & & 4 \\
\hline & Analisis imbuhan & & 4 \\
\hline & Ulang catat & & 1 \\
\hline & Analisis penggunaan ayat & & 1 \\
\hline \multirow[t]{5}{*}{ Memori } & Menyebut dengan kuat & 5 & 9 \\
\hline & Sinonim & & 9 \\
\hline & Antonim & & 9 \\
\hline & Guna perkataan dalam ayat & & 5 \\
\hline & Pengetahuan lepas & & 3 \\
\hline \multirow[t]{3}{*}{ Sosial } & Komunikasi & 3 & 3 \\
\hline & Perbincangan & & 3 \\
\hline & Bertukar-tukar kosa kata & & 1 \\
\hline Meta-kognitif & Uji dengan ujian perkataan & 1 & 1 \\
\hline \multirow[t]{2}{*}{ Unsur Islam } & Insya Allah & 2 & 2 \\
\hline & Alhamdulillah & & 1 \\
\hline Jumlah & & 23 & \\
\hline
\end{tabular}

\section{Sub strategi untuk pengukuhan makna}

Dapatan analisis data protokol perlantangan fikiran dan temu bual menunjukkan pelbagai sub strategi telah digunakan untuk tujuan pengukuhan makna kosa kata yang telah dikuasai. Sebanyak 23 jenis sub strategi telah diaplikasikan oleh peserta kajian. Strategi kognitif merupakan strategi yang paling banyak digunakan iaitu 12 jenis sub strategi. Maklumat terperinci pengaplikasian sub strategi kognitif oleh setiap peserta kajian dapat diamati melalui Jadual 7. 
Dapatan seperti Jadual 7 menunjukkan strategi menggunakan kad imbas, strategi ulang sebutan, strategi membaca ayat contoh, strategi menterjemahkan ayat dan strategi mencatat merupakan empat sub strategi kognitif yang paling popular dalam kalangan peserta kajian. Strategi menganalisis penggunaan ayat pula adalah sub strategi yang paling kurang popular. Strategi tersebut hanya digunakan oleh seorang peserta sahaja. Strategi mencatat digunakan oleh lapan orang peserta, strategi analisis pembentukan kata digunakan oleh tujuh orang peserta dan strategi analisis pola digunakan oleh enam orang peserta. Tiga strategi lagi iaitu strategi menggunakan gambar, strategi analisis kata dasar dan strategi analisis imbuhan digunakan oleh empat orang peserta.

Dapatan analisis data protokol perlantangan fikiran dan pemerhatian juga menunjukkan lima sub strategi memori digunakan oleh peserta kajian untuk pengukuhan makna kosa kata yang telah dikuasai. Analisis juga menunjukkan setiap peserta menggunakan antara tiga hingga lima jenis sub strategi untuk tujuan tersebut. Maklumat terperinci pengaplikasian sub strategi memori oleh setiap peserta kajian dapat diamati melalui Jadual 7.

Jadual 7 menunjukkan tiga jenis sub strategi memori menjadi pilihan utama peserta untuk mengukuhkan penguasaan makna kosa kata. Strategi tersebut ialah strategi menyebut dengan kuat, strategi menghubungkan kosa kata dengan sinonim dan strategi menghubungkan kosa kata dengan antonim. Strategi menggunakan pengetahuan lepas pula adalah strategi yang paling kurang menjadi pilihan peserta. Strategi ini hanya digunakan oleh tiga orang peserta sahaja.

Analisis sub strategi sosial daripada data temu bual pula menunjukkan tiga jenis strategi telah digunakan untuk memantapkan penyimpanan makna. Bilangan peserta yang menggunakan sub strategi sosial adalah di antara satu hingga tiga orang peserta. Jadual 7 menunjukkan strategi komunikasi digunakan oleh tiga orang peserta, strategi perbincangan digunakan oleh tiga orang peserta dan strategi bertukar-tukar kosa kata digunakan oleh seorang peserta. Paparan Jadual 7 juga menunjukkan strategi sosial kurang menjadi pilihan peserta untuk pengukuhan penguasaan makna kosa kata.

Dapatan analisis data protokol perlantangan fikiran menunjukkan hanya satu sub strategi meta kognitif sahaja iaitu strategi uji diri dengan ujian perkataan digunakan untuk pengukuhan penguasaan makna kosa kata. Paparan Jadual 7 menunjukkan strategi meta kognitif kurang mendapat perhatian peserta kajian untuk pengukuhan penguasaan makna kosa kata. Hanya seorang peserta dengan satu sub strategi sahaja digunakan untuk tujuan tersebut. 
Analisis data protokol perlantangan fikiran menunjukkan peserta kajian menggunakan dua sub strategi Islam untuk memantapkan penyimpanan makna kosa kata berimbuhan. Sub strategi tersebut ialah ucapan in sya Allah dan alhamdulillah. Maklumat lebih terperinci penggunaan sub strategi unsur Islam adalah seperti Jadual 7.

Dapatan seperti paparan Jadual 7 menunjukkan hanya tiga peserta kajian sahaja yang menggunakan sub strategi unsur Islam untuk mengukuhkan penguasaan makna kosa kata berimbuhan. Penggunaan strategi unsur Islam juga terbatas kepada dua sub strategi sahaja.

\section{PERBINCANGAN}

Secara umumnya peserta kajian menggunakan pelbagai strategi untuk mempelajari kosa kata tersebut. Dapatan ini seiring dengan beberapa dapatan kajian seperti Lawson dan Hogben (1996), Al-Shuwairekh (2001), Dakun (2006) dan Zhang (2011) yang mendapati pelajar cemerlang menggunakan pelbagai strategi ketika mepelajari kosa kata baharu. Sebanyak 42 jenis sub strategi telah digunakan oleh peserta kajian untuk mempelajari kosa kata berimbuhan. Strategi penentuan merupakan strategi yang paling banyak digunakan oleh peserta kajian. Dapatan kajian menunjukkan 17 jenis sub strategi penentuan telah digunakan oleh peserta kajian. Ia diikuti oleh strategi kognitif dengan 12 jenis sub strategi, strategi memori dengan enam sub strategi, strategi sosial dengan tiga jenis dan strategi unsur Islam dan meta kognitif dengan satu jenis sub strategi.

Dari aspek tumpuan penggunaan strategi, analisis kekerapan menunjukkan sebahagian peserta lebih memberikan tumpuan kepada strategi penemuan dan sebahagian lagi kepada strategi pengukuhan. Dapatan ini menggambarkan bahawa pelajar cemerlang yang terlibat dalam kajian ini adalah pelajar yang aktif dalam pembelajaran mereka. Ia seiring dengan dapatan kajian Ahmed (1988) dan Sanaoui (1995) mendapati pelajar cemerlang adalah pengguna strategi yang aktif berbanding pelajar kurang cemerlang.

Dapatan kajian juga menunjukkan strategi pengukuhan makna kosa kata yang menjadi pilihan majoriti peserta ialah strategi mengulang sebutan, membaca ayat contoh, menterjemahkan ayat contoh, mencatat dan menyebut dengan kuat. Dapatan ini memberi gambaran bahawa peserta kajian kurang menggunakan aktiviti mental secara mendalam untuk meneguhkan penguasaan makna kosa kata berimbuhan yang telah dipelajari. Hal ini demikian kerana strategi tersebut tidak memerlukan penggunaan operasi minda secara mendalam. Ianya berada dalam kelompok pengulangan dan huraian mudah sahaja. Dapatan ini seiring dengan 
kajian Moir dan Nation (2008) yang mendapati menghafal adalah strategi yang paling biasa digunakan oleh sembilan daripada sepuluh peserta kajiannya. Menurut Lawson dan Hogebon (1996) strategi tersebut merupakan strategi yang sangat biasa digunakan oleh pelajar ketika mempelajari sesuatu kosa kata. Hal demikian menyebabkan mereka menghadapi kesukaran untuk mendapatkan kembali makna kosa kata yang telah disimpan di dalam sistem ingatan.

Menurut Schmitt (1997) bukti daripada kajian bidang psikologi kognitif menunjukkan aktiviti yang memerlukan operasi minda secara mendalam akan meningkatkan tahap keberkesanan sesuatu pembelajaran.Kegagalan untuk mendapatkan semula berlaku apabila kita tidak dapat mencari maklumat yang disimpan dalam ingatan jangka panjang kerana proses pembelajaran hanya pada tahap hafalan sahaja (Banikowski \& Mehring, 1999). Lantaran itu Lawson dan Hogebon (1996) berpandangan penggunaan prosedur penghuraian ketika pembelajaran kosa kata adalah lebih berguna untuk tujuan mengingat berbanding prosedur pengulangan. Menurut Schmitt dan Schmitt (1993) kualiti sesuatu pembelajaran bergantung kepada bagaimana sesuatu maklumat diproses oleh mental. Sekiranya maklumat tersebut tidak diproses secara mendalam, ia mungkin tidak dapat kekal di dalam ingat dan mudah dilupakan.

Dapatan kajian juga menunjukkan tahap penggunaan strategi metakognitif dalam kalangan peserta adalah sangat minimun dengan hanya satu sub strategi sahaja digunakan oleh peserta kajian. Dapatan ini berlawanan dengan dapatan kajian lain seperti Yazdi dan Kafipour (2014) dan Dakun (2006) yang mendapati tahap penggunaan strategi meta kognitif dalam kalangan peserta kajian mereka adalah tinggi. Dapatan ini menunjukkan peserta kajian lebih banyak bergantung kepada pengajaran guru dan kurang kemampuan untuk mengurus pembelajaran kosa kata secara sendirian. Akibatnya mereka menghadapi masalah untuk menguasai kosa kata baharu adalah dengan lebih berkesan. Menurut Shannon (2008) strategi meta kognitif sangat bernilai untuk membentuk sikap pembelajaran kendiri dalam diri pelajar. Hal ini demikian kerana strategi meta kognitif membantu pelajar menyedari lompang yang terdapat pada pengetahuan linguistik dan menggunakan pendekatan pembelajaran yang lebih sesuai untuk meningkatkan kemahiran (Alavi \& Kaivanpanah, 2009). Menurut Nation (2006) pencapaian pelajar yang mempunyai sikap pembelajaran kendiri adalah lebih baik berbanding pelajar yang tidak mempunyai sikap pembelajaran kendiri.

\section{KESIMPULAN}

Kajian ini telah meneroka penggunaan strategi pembelajaran kosa kata berimbuhan bahasa Arab dalam kalangan pelajar cemerlang. Ia telah membekalkan maklumat yang sangat berfaedah tentang cara pelajar cemerlang 
mengaplikasikan strategi pembelajaran ketika mempelajari kosa kata berimbuhan bahasa Arab. Tahap penggunaan yang rendah dan cara pengaplikasian secara mendatar seperti yang dibincangkan dalam dapatan kajian menunjukkan tahap penguasaan dan kefahaman pelajar cemerlang terhadap strategi pembelajaran kosa kata masih rendah. Keadaan demikian menuntut guru bahasa Arab untuk mengajarkan kepada pelajar bahasa Arab strategi pembelajaran yang lebih berkesan agar pembelajaran kosa kata menjadi lebih efektif.

Kajian ini juga merupakan kajian awal yang mengkaji penggunaan strategi pembelajaran kosa kata dalam kalangan pelajar cemerlang ketika mempelajari kosa kata berimbuhan bahasa Arab. Kajian selanjutnya boleh dijalankan dengan menjalankan kajian perbandingan penggunaan strategi pembelajaran kosa kata berimbuhan di antara pelajar cemerlang dengan lemah. Tumpuan kajian juga boleh diperluaskan kepada bentuk pola kata yang lain.

\section{RUJUKAN}

Abhakorn, J. (2008). The implications of learner strategies for second or foreign language Teaching. ARECLS, 5, 186-204.

Ahmad Azman Mokhtar, Rafizah Mohd Rawian, Mohamad Fadhili Yahaya, Azaharee Abdullah, \& Abdul Rashid Mohamed. (2009). Vocabulary learning strategies of adult ESL learners. The English Teacher, 38, 133-145.

Ahmed, M. O. (1988). Vocabulary learning strategies: A case study of Sudanese learners of English. Unpublished doctoral dissertation, University College of North Wales.

Ahmed, M. O. (1989). Vocabulary learning strategies. In P. Meara (Eds.), Beyond words, (pp. 3-14). London: British Association for Applied Linguistics.

Al-Afghani, S. (2003). Mujaz fi Qawaid al-Lughah al-Arabiyyah. Beirut: Dar al-Fikr.

Alavi, S. M., \& Kaivanpanah, S. (2009). Examining the role of individual differences in lexical inferencing. Journal of Applied Sciences, 9(15), 2829-2834. http://dx.doi.org/10.3923/jas.2009.2829.2834

Al-Batal, M. (2007). Arabic and national language educational policy. The Modern Language Journal, 91(2), 268-271. http://dx.doi.org/10.1111/j.15404781.2007.00543_10.x

Al-Batal, M. (2006). Playing with words: Teaching vocabulary in the Arabic curriculum. In K. Wahba, Z. Taha, \& E. England (Eds.), Handbook for Arabic Language Teaching Professionals in the 21st Century (pp. 331-340) New Jersey: Lawrence Erlbaum Associates.

Al-Ghalayini, M. (1993). Jamic al-Durus al-Arabiyyah. Beirut: Al-Maktabah al-Asriyyah. Alhashemi, A., \& Mahmoud, A. (2012). Vocabulary learning strategies used by learners of Arabic as a foreign language in the University of Islamic Sciences in Malaysia and their beliefs about vocabulary. Journal of Educational Sciences, $8(2), 105-117$. 
Al-Qahtani, A. L. (2005). The use of vocabulary learning strategies by EFL learners at three different educational levels. Unpublished doctoral dissertation, University of Essex.

Al-Shamsani, Abu Uwais Ibrahim. (1997). Durus fi Ilm al-Sorf. Riyad: Maktabat al-Rushd, KSA.

Al-Shuwairekh, S. (2001). Vocabulary learning strategies used by AFL (Arabic as a Foreign Language) learners in Saudi Arabia. Unpublished doctoral dissertation,University of Leeds.

Al-Thamaniniyy, U. S. (1999). Syarh al-Tâ̂rif. Riyad: Maktabat Rushd.

Anderson, J. A. (1983). Cognitive and psychological computation with neural models. IEEE Transactions on Systems, Man and Cybernetics, 5, 799-815.

Asgari, A. \& Ghazali Mustapha. (2011). The type of vocabulary learning strategies used by ESL students in university Putra Malaysia. English Language Teaching 4(2), 84-90. http://dx.doi.org/10.5539/elt.v4n2p84

Asgari, A., \& Mustapha, G. B. (2010). Vocabulary attrition among adult English as a foreign language persian learners. English Language Teaching, 3(4), 62-70. http://dx.doi.org/10.5539/elt.v3n4p62

Atkinson, R. C., \& Shiffrin, R. M. (1968). Human memory: A proposed system and its control processes. Psychology of Learning and Motivation, 2, 89-195. http://dx.doi.org/10.1016/S0079-7421(08)60422-3

Auerbach, C. F., \& Silverstein, L. B. (2003). Qualitative data: An introduction to coding and analysis. New York: NYU Press.

August, D., Carlo, M., Dressler, C., \& Snow, C. (2005). The critical role of vocabulary development for English language learners. Learning Disabilities Research and Practice, 20(1), 50-57. http://dx.doi.org/10.1111/j.1540-5826.2005.00120.x

Azizi Yahaya, Shahrin Hashim, Jamaludin Ramli, Yusof Boon, \& Abdul Rahim Hamdan. (2007). Menguasai penyelidikan dalam pendidikan. Selangor: PTS Professional Publishing Sdn. Bhd.

Banikowski, A. K., \& Mehring, T. A. (1999). Strategies to enhance memory based on brain-research. Focus on Exceptional Children, 32(2), 1-16.

Cameron, L. (2001). Teaching languages to young learners. Cambridge, UK: Cambridge University Press. http://dx.doi.org/10.1017/CBO9780511733109

Catalan, R. M. J. (2003). Sex differences in L2 vocabulary learning strategies. International Journal of Applied Linguistics, 13(1), 54-77. http://dx.doi.org/ 10.1111/1473-4192.00037

Cook, V. (2013). Second language learning and language teaching. New York, NY: Routledge.

Cotton, D., \& Gresty, K. (2006). Reflecting on the think-aloud method for evaluating elearning. British Journal of Educational Technology, 37(1), 45-54.

Creswell, J. W. (2012). Qualitative inquiry and research design: Choosing among five approaches. Thousand Oaks, CA: Sage publications.

Dakun, W., \& Gieve, S. (2006). Learning environments and the use of vocabulary learning strategies: A case study of Chinese learners. Indonesian Journal of English Language Teaching 4(1), 56-89.

Dakun, W. (2006). Learning strategies and implications for second language teaching. Indonesian Journal of English Language Teaching 2(2), 72-82. 
Ellis, R. (1985). Understanding second language acquisition. Oxford: Oxford University Press.

Fu, I. P. P. (2005). Student approaches to learning Chinese vocabulary. PhD dissertation, Virginia Polytechnic Institute and State University.

Gagne, F. (1993). Constructs and models pertaining to exceptional human abilities. In K. A. Heller, F. J. Monks, \& A. H. Passow (Eds.), International handbook of research and development of giftedness and talent (pp. 69-87). Oxford: Pergamon Press.

$\mathrm{Gu}$, Y. (1994). Vocabulary learning strategies of good and poor Chinese EFL learners. ERIC Document Reproduction Service No. ED 370411.

Harun Baharudin, \& Zawawi Ismail. (2014). Vocabulary learning strategies and Arabic vocabulary size among pre-university students in Malaysia. International Education Studies, 7(13), 219-226. http://dx.doi.org/10.5539/ies.v7n13p219

Harun Baharudin. (2014). Strategi pembelajaran kosa kata bahasa arab dalam kalangan pelajar sekolah menengah agama di Malaysia. Unpublished doctoral dissertation, Universiti Malaya, Kuala Lumpur.

Intaraprasert, C. (2004). ETS students and vocabulary learning strategies: A preliminary investigation. Unpublished research, Suranaree University of Technology, Nakhon Ratchasima, Thailand.

Khoury, G. (2008). Vocabulary acquisition in Arabic as a foreign language: The root and pattern strategy. Unpublished doctoral dissertation, Boston University.

Lawson, M. J., \& Hogben, D. (1996). The vocabulary-learning strategies of foreignlanguage students. Language Learning, 46(1), 101-135. http://dx.doi.org/ 10.1111/j.1467-1770.1996.tb00642.x

Lightbown, P. M., \& Spada, N. (1994). An innovative program for primary ESL students in Quebec. TESOL quarterly, 28(3), 563-579. http://dx.doi.org/ $10.2307 / 3587308$

Mays, N., \& Pope, C. (1995). Qualitative research: rigour and qualitative research. BMJ, 311(6997), 109-112. http://dx.doi.org/10.1136/bmj.311.6997.109

Mohd. Sahandri Ghani Hamzah, Kafipiur, R., \& Saifuddin Kumar Abdullah. (2009). Vocabulary learning strategies of Iranian undergraduate EFL students and its relation to their vocabulary size, European Journal of Social Sciences, 11(1), $39-50$.

Moir, J., \& Nation, P. (2008). Vocabulary and good language learners. In C. Griffiths (Ed.), Lessons from good language learners (pp. 159-196). Cambridge: Cambridge University Press. http://dx.doi.org/10.1017/CBO9780511497667.015

Mufidah Abd Razak. (2008). Keberkesanan kaedah kata kunci untuk memperoleh kosa kata bahasa Arab: Kajian lapangan pengajaran bahasa Arab sebagai bahasa kedua di Malaysia. Unpublished Masters thesis, Fakulti Ilmu Wahyu Dan Sains Kemanusiaan, Universiti Islam Antarabangsa Malaysia.

Naiman, N., Fröhlich, M., Stern, H. H., \& Todesco, A. (1978). The good language learner (Research in Education Series No. 17). Toronto, Canada: Ontario Institute for Studies in Education.

Nation, I. S. P. (2006). Language education: Vocabulary. In K. Brown (Ed.), Encyclopedia of Language and Linguistics ( ${ }^{\text {nd }}$ ed., pp. 494-499). Oxford: Elsevier. 
Nik Hanan Mustapha, \& Rabiatul Aribah Muhd Isa@Omar. (2014). Arabic vocabulary learning strategies among non-native speakers: A case of IIUM. GJAT, 4(2), $125-133$.

Nik Mohd Rahimi Nik Yusoff, Zahriah Hussin, \& Wan Normeza Wan Zakaria. (2014). Pembelajaran kosa kata bahasa. Jurnal Teknologi, 67(1), 33-38.

Norhayuza Mohamad. (2006). Penggunaan strategi pemetaan dalam pengajaran kosa kata bahasa Arab. Unpublished doctoral dissertation, Universiti Malaya.

Nunan, D. (1999). Second language teaching and learning. Boston, MA: Heinle and Heinle Publishers.

Oxford, R., \& Crookall, D. (1989). Research on language learning strategies: Methods, findings and instructional issues. The Modern Language Journal, 73(4), 404419. http://dx.doi.org/10.1111/j.1540-4781.1989.tb05321.x

Oxford, R. L. (1990). Language learning strategies and beyond : A look at strategies in the context of styles. Shifting the instructional focus to the learner, 35-55.

Patton, M. Q. (1990). Qualitative evaluation and research methods. Thousand Oaks, CA: SAGE Publications.

Qahtani, A. L. (2005). The use of vocabulary learning strategies by EFL learners at three different educational levels. $\mathrm{PhD}$ dissertation, University of Essex.

Rabiatul Aribah Muhd Isa, Nik Hanan Mustapha, Tg Ainul Farha Tg Abdul Rahman, \& Nadhilah Abdul Pisal (2014). Vocabulary learning strategies: Differences between arabic and non-arabic majoring students at the International Islamic University Malaysia. Middle-East Journal of Scientific Research, 20, 28-32.

Richards, J. C., \& Schmidt, R. (2002). Longman dictionary of language teaching and applied linguistics (3rd ed.). London: Pearson Education.

Rigney, J. W. (1978). Learning strategies: A theoretical perspective. In H. F. O'Neil Jr (Eds.), Learning strategies (pp. 165-205). New York: Academic Press.

Rubin, J. (1975). What the "good language learner" can teach us. TESOL quarterly, 41-51. http://dx.doi.org/10.2307/3586011

Sagarra, N., \& Alba, M. (2006). The key is in the keyword: L2 vocabulary learning methods with beginning learners of Spanish. The Modern Language Journal, 90(2), 228-243. http://dx.doi.org/10.1111/j.1540-4781.2006.00394.x

Sanaoui, R. (1995). Adult learners' approaches to learning vocabulary in second languages. The Modern Language Journal, 79(1), 15-28. http://dx.doi.org/ 10.1111/j.1540-4781.1995.tb05410.x

Schmitt, N., \& Schmitt, D. R. (1993). Identifying and assessing vocabulary learning strategies. Thai TESOL Bulletin, 5(4), 27-33.

Schmitt, N. (1997). Vocabulary learning strategies. In N. Schmitt \& M. McCarthy (Eds.), Vocabulary: Description, acquisition and pedagogy (pp. 199-227). Cambridge: Cambridge University Press.

Shannon, S. V. ( 2008). Using metacognitive strategies and learning styles to create self-directed learners. Institute for Learning Styles Journal, 1, 14-28.

Stern, H. H. (1975). What can we learn from the good language learner? Canadian Modern Language Review, 31(4), 304-318.

Takač, V. P. (2008). Vocabulary learning strategies and foreign language acquisition (Vol. 27). New York: Multilingual Matters.

Tesch, R. (1990). Qualitative research: analysis types \& software tools. Bristol, PA: Falmer Press. 
Mohd Zaki Ismail et al.

Wan Abdul Hayyi Wan Omar, Mohd Shahrizal Nasir, Mohd Firdaus Yahaya, \& Zulazhan Ab. Halim. (2014). Penguasaan kosa kata arab menerusi aktiviti jawlah lughawiyyah. Prosiding Seminar Pengajaran \& Pembelajaran Bahasa Arab 2014.

Wenden, A \& Rubin, J. (1987). Learner strategies in language learning. New Jersey: Prentice Hall.

Yazdi, M. \& Kafipour, R. (2014). A qualitative study of vocabulary learning strategies applied by Iranian undergraduate EFL learners in real learning setting. English Language Teaching, 7(7), 1-7. http://dx.doi.org/10.5539/elt.v7n7p1

Zamri Mahamod \& Mohamed Amin Embi. (2005). Penggunaan strategi pembelajaran bahasa untuk menguasai kemahiran membaca. Jurnal Teknologi 42(E), 1-18.

Zhang, Y. H. (2011). The use of vocabulary learning strategies by good and poor language learners: A case study of Chinese non-English major sophomores. Masters dissertation, Kristianstad University, Sweden.

Qabawah, F. (1988). Tasrif al-Asma' wa al-Afal. Beirut : Maktabat al-Maarif. 